\title{
The reliance of the Jordanian daily newspapers on the Jordan News Agency as the main source of news and its impact on content
}

\section{Dr. Majid numan Al-Khudari}

Associate Professor, Department of Digital Media -Applied Science Private University

Dr.muhamad lamel al_quraan

Assistant Professor in the Department of Digital Media- Applied Science Private University

Dr. Ashraf Faleh Al-Zoubi,

Zarqa Private University, Faculty of Information

\begin{abstract}
Since the emergence of news agencies in the world, these agencies have become part of the global and local media scene, and newspapers cannot dispense with the services provided by agencies, especially the major news agencies in the world, which are the French Sons Agency, the British Sons Agency, the two American news agencies, the Associated Press and the United Press, as these agencies have become It controls the flow of news across the world, and newspapers prefer to rely on them for news due to the low cost and easy access to news.

In Jordan, like other countries of the world, the media relies heavily on news agencies to obtain news, as major news agencies are relied upon to obtain international and Arab news, while the Jordanian Sons Agency "Petra" is relied upon to obtain local news.

The Jordanian News Agency dominates the Jordanian newspapers that publish the news issued by this agency, which is considered the official and only official agency in the Hashemite Kingdom of Jordan. This agency focuses on publishing official news, especially news issued by the royal court, the presidency of the government and other official institutions, as there is almost a monopoly on these news. By the agency that provides its services to Jordanian newspapers, Jordanian news sites, and radio and television stations for free.

This study is classified within descriptive research, and the researcher relied on the survey method. Three Jordanian daily newspapers were tracked, namely Al-Rai, Al-Dustur, and Al-Ghad. All news published in these three newspapers were scanned for a period of fifteen days.
\end{abstract}

The study revealed that $38 \%$ of the news published in these newspapers

Extracted from Jordan News Agency

The study also found that the three daily newspapers under consideration depend heavily on the Jordan News Agency for news

This makes the relationship between agencies and newspapers almost completely dependent.

Article Received: 18 October 2020, Revised: 3 November 2020, Accepted: 24 December 2020

\section{Introduction}

News agencies appeared in the eighteenth century, when the first news agency in the world was established in France, which is the Haves News Agency, which was founded in $1835 \mathrm{CE}$ and named after its founder, and from that year began its mission to provide newspapers with local and international news, and after the emergence of this agency, dozens of international, regional and local news agencies appeared in various Countries of the world .

News agencies have become an integral part of the media landscape in the world. Newspapers have greatly increased their dependence on these agencies, and their news that is broadcast through news agencies has become a large proportion of the news published in newspapers. The reliance of newspapers in the world on news agencies has increased due to the low cost of their news The economic aspect and the inability of newspapers to appoint correspondents for them in all hot places in the world.

News agencies are the main source of news in various countries of the world. Newspapers partner with these agencies that broadcast hundreds of news bulletins daily.

The daily newspapers in Jordan, like other newspapers in the world, rely on international, regional and local news agencies to obtain news. 
According to the study "Al-Khodari 2016", more than $90 \%$ of the global news published in Jordanian daily newspapers comes from private international agencies, such as the French News Agency and the British News Agency. Reuters.

The daily newspapers in Jordan, "Al-Rai, AlDustur, and Al-Ghad" rely on the Jordan News Agency to obtain local news, especially official news related to the activities of the government and the Royal Court, as they rely heavily on the Jordanian News Agency, "Petra", to obtain these news.

This study comes to reveal the extent of the adoption of Jordanian daily newspapers

Al-Rai, Al-Ghad, and Al-Dustour, the Jordan News Agency must obtain local news and its effect on the similarity of content between these newspapers.

Hence, this survey study comes in order to reveal the extent of these newspapers' dependence on the Jordanian News Agency, as the news agency plays an important role in transmitting and exchanging news through written, visual and audio media.

The Jordan News Agency was established by royal decree in $1969 \mathrm{AD}$ and is fully owned by the government and provides many services to newspapers, as it broadcasts more than a hundred news in Arabic on its website and fifty news in English and provides televised news services, pictures and archive services, as the agency's archive contains more than a million Press release, "the official website of the Jordan News Agency."

\section{Theoretical framework:}

It is hoped that this study will contribute significantly to enriching the theoretical side by extracting results that may contribute to the development of the studied side and add something new to the subject of the study or develop some existing theories or explain the phenomenon of the study and clearly clarify the existing relationship between the Jordanian News Agency "Petra And newspapers in Jordan and around the world.
The researcher considered that the Jordan News Agency "Petra" is the independent variable and that the daily newspapers that use this agency's products are the dependent variable.

The researcher conducted his study on three daily Jordanian newspapers, which are Al-Rai, AlDustour and Al-Ghad newspaper. The local news sources in these newspapers were analyzed.

The Jordanian Sons Agency is one of the most important sources at all in providing Jordanian newspapers with news, reports, interviews, investigations and photos, as it covers all news that occurs in Jordan and a number of Arab and European countries.

It covers special news of the government and official bodies and is often provided with special news that the three daily newspapers under study may not obtain, which makes these newspapers publish news of the Jordanian News Agency.

\section{News agencies:}

They are media institutions that operate through a wide network of delegates and correspondents spread all over the world and provide means of communication with news that they obtain from all local, governmental, internal and external sources, as well as transmit images, radio investigations, criticism, messages, etc. (Muhammad Al-Far, 2006, p. 354).

The news agency is known as a media outlet that has a network of correspondents, and can collect news materials and still and moving images around the clock from a large number of editors who re-edit these materials so that they can be published in other media.

There is no doubt that news agencies have witnessed remarkable developments in recent years in their content, management, working methods, areas of spread, expansion, influence, political, economic, social and cultural role, the use of the latest scientific and technical equipment, imports, external services and subscribers, in addition to the editorial methods used in them, and the diversity in the use of different expert arts. And developing it by 
introducing professional touches to it. This diversity in the use of editorial methods and news arts has led to a remarkable qualitative shift in the form and content of news materials for news agencies, and has accompanied the qualitative shift witnessed by most of the media in the world, in terms of professional performance in the first place.

The emergence of news agencies goes back to the year 1832 AD, when Charles Louis Havas established in France the first news agency in the world called Havas, and the French government bought it from its owners after that, and then the Germans seized it during World War II ... and there it was. A secret news agency that supports the resistance against the German occupation, along with the independent France News Agency, which was founded by the Liberals in London, and from these agencies together, the French News Agency, Agence France-Presse, was established in $1944 \mathrm{CE}$, and this agency covers most countries of the world with its correspondents and offices, as it has offices currently in two hundred countries around The world is considered one of the largest news agencies in the world. Hundreds of Arab newspapers depend on the news published by this agency, which is broadcast around the clock.

After this agency appeared in the world, agencies began to appear successively, and the major powers began to sense the importance of these agencies, which then became an integral part of the modern state and a symbol of the national sovereignty of each country; This necessitated that every country in the world have its own news agency through which it expresses the state's policies and reports its news (Muhammad AlQuozi, 2007).

After the French News Agency, the emergence of agencies in the world continued, so the Reuter Sons Agency appeared in France in 1850, and then moved to the United Kingdom. The agency owns four press unions whose slogan is "speed and accuracy". Its writers and correspondents are spread in most countries and regions of the world, and today it provides its services. To most of the media institutions in the world. It is a news agency of an international nature that is considered one of the most important agencies in the world. It broadcasts more than five million words per day and has offices in two hundred countries.

In 1848, the Associated Press News Agency was established and its services were limited to the six newspapers that contributed to its founding, then it was closed by a court ruling in 1943 because it was not legal, but it returned strongly to provide its services inside and outside the US states, and this agency is currently providing its services to most of the world's newspapers and stations Radio and television inside and outside the United States of America.

One of the most important agencies in the world is the United Press Agency, which was founded in 1907 and was called the Press Union Foundation, after its merger with the International News Agency (after about fifty-one years) and named after its current name. Many media institutions inside and outside the United States of America, and it has many correspondents in various regions of the world; In recent years, it has suffered a financial crisis, which has prompted those in charge to offer its shares for sale.

TASS is considered one of the important agencies in the world and it is the only source of news in the former Soviet Union, and it was at that time dealing with news of the Communist Party and the Soviet government ... and it joined the Russian Federation after the collapse of the Soviet Union, but its strength in terms of coverage and services is not comparable to the two agencies of France Press. And Reuters (Hosni Muhammad, 2001).

After the Second World War, many countries of the world established their own national news agencies to limit the influence of international news agencies. In 1956, the Egyptian newspapers established the "Egyptian Middle East" news agency, then they were affiliated with the public sector in 1962, and then a private agency owned by Moroccan citizens was established, which is 
the "Moroccan Agency Arab News »in 1959, and then Arab governments established national news agencies, which are historically:The Iraqi News Agency, the Africa News Agency in Tunisia, the Algerian News Agency, the Arab Revolution News Agency in Libya, the Jordanian News Agency, the Syrian Arab News Agency / SANA, the Aden News Agency, the Saba News Agency, the Saudi Press Agency, the Palestinian News Agency, the Sudan News Agency, The Mauritanian Press Agency, the Qatar News Agency, the Kuwait News Agency, and the Emirates News Agency.Most of these agencies suffer from their official dependency on governments, and their directors are appointed from the highest political authorities, which contributes to the narrow margin of freedom for those in charge, and these agencies suffer from a shortage of human competencies, and a lack of Its offices and correspondents abroad, as well as many of them suffer from weak financial, technical, editorial and administrative capabilities and poor internal communication, which made the scope of work for most of them limited to providing local media and some institutions with news inside their countries (El-Far, 2006).

\section{Journalism in Jordan}

In Jordan, the press appeared later than the countries of the world due to the policy of the Ottoman Empire, which was concerned with military matters at the expense of other aspects of the state, and after independence from Turkey, newspapers began to appear in Jordan, where the newspaper Al-Haq Yo Io, which was founded by Prince Abdullah bin Al-Hussein when he came to Jordan from the Hijaz to establish The Emirate of Transjordan in 1921 A.D. The first Jordanian newspaper. The Jordanian newspapers, which were suffering from a lack of resources, were published in succession. In 1967, the newspaper was established. Al-Dustour newspaper was established in 1971 A.D. Al-Rai Newspaper was established and in 1993 A.D. Al-Ghad newspaper was established (Al-Khodari, 2016)
The Jordanian press passed through its historical development in three stages: First: the emirate's press, which extended from 1921 (the date of the emirate's establishment to 1946). Second: The Kingdom's press, which extended from 1946 (the kingdom's independence) to 1970. Third: The modern phase that can be divided into two phases: The first: It extended from 1970 to 1989, when the Jordanian press was at that time characterized by financial stability and technical progress. And the second: It started from 1989, when Jordan underwent a democratic transition, until now

We find that the birth of the Jordanian press coincided with the emergence of the political entity of the Emirate of Transjordan on April 11, 1921. "Haq Yo Al-Haq" is considered the first newspaper in Jordan, and that was in the camp of Prince Abdullah the First in Maan. After the printing press was introduced in 1923, "Al Sharq Al Arabi" newspaper was published, an official newspaper that was published weekly or bimonthly. The name of this newspaper was changed in 1926 to become the "Official Gazette" of the Transjordan government, then this name changed from Independence to the "Official Gazette" of the Kingdom for the Hashemite Jordanian It is still issued until now.

The year 1927 witnessed a real development in the issuance of newspapers through the private sector. The newspapers "Jazirat al-Arab" by Husam al-Din al-Khatib, "Sada al-Arab" in favor of al-Samadi, and "Jordan" by Khalil Nasr, which remained published until 1982, and the Jordanian poet Mustafa Wahbi al-Tal "Al-Anbaa" newspaper was published, but the first issue was confiscated from the printing press. In the thirties of the twentieth century, newspapers and magazines were published that were not sustainable, such as: "Al-Hikma" magazine; The Charter; "And loyalty"; ... and others

In the thirties, a newspaper and magazines were published, such as Al-Hikma Magazine, Al4779 
Mithaq, Al-Wafa newspaper, and Al-Jazeera AlArabia.

After the independence of the Hashemite Kingdom of Jordan on May 25, 1946, and the occupation of Palestine in 1948 AD, several newspapers were published, including: Al-Raed magazine by Amin Abu Al-Shaar, which was speaking on behalf of the Jordanian People's Party; The Jihad Newspaper 1947; And the Renaissance in 1949, which was issued by the Arab Renaissance Party. After the Nakba of 1948, a number of Palestinian journalists moved with their newspapers to Jordan.

Accordingly, the Palestine and Defense newspapers were published in Jordan and were published in Palestine, and the Palestine newspaper was published in 1911 and remained in Palestine until the Nakba, then moved to Amman. As for the period of nationalism, especially the Nasserite, which prevailed in the Arab street in the fifties and sixties (in the name of Sakkijha 1999 AD), the Jordanian government at the time, headed by Mr. Wasfi al-Tal, felt that the Jordanian press, which was issued from Jerusalem, traces its roots back to the Palestinian press. She was unable to counter the Nasserite nationalist line that used the ether to spread propaganda for his ideology, or perhaps she was in favor of that line. That is why the government issued a new Publications Law in 1967, in place of the 1955 law, in order to be able to effectively control undisciplined or ineffective press.

Al-Dustour newspaper is the only daily newspaper that existed during the period from 1967-1970 despite the publication of Al-Defense newspaper for a short period. At a time when the first approached the state approach, without facing Palestinian resistance; The second was closer to the ideas of organizations. This contributed to convincing the government of Mr. Wasfi al-Tal, after he settled matters, of the need to publish a newspaper that speaks for the government.

Thus, the Jordanian government issued a decision
No. (26) on May 13, 1971, to establish a thinktank and a government newspaper that would be "able to read political changes", which is the "Jordanian Press Foundation" and appointed Mr. Amin Abu al-Shaar as the first general manager of this institution, The first production of this institution was "Al-Rai Newspaper" according to a decision of the Prime Minister on May 18, 1971, and the first issue of it was published on June 2.

It seems that the aim of this step was to issue a "semi-official" newspaper that speaks on behalf of the government, as is the case in a number of Arab countries.

After its publication, Al-Rai newspaper became the second official newspaper in the history of the Hashemite Kingdom of Jordan after Al-Sharq AlArabi newspaper which was published in 1923. Its publication also bore a paradox that bears indications that its release to the market preceded the official licensing process by 76 days, so it is not necessary to license it as long as the government itself is Its owner.

Although the government has adopted this institution, the newspaper since its inception; However, the "Al-Rai" newspaper that emanated from it failed to meet the standard that its owners were looking for (Essam Al-Mousa, 1997)

The government sought to leave the press in the hands of the private sector (on the condition that it not deviate from the state's line), and the institution transformed from a "public shareholding institution" to a "private joint-stock institution," as this process was carried out in stages beginning in 1973 and ending in 1975. So the ownership of the institution was transferred in The beginning was to the Arab National Union (the political organization speaking in the name of the state at the time through which King Hussein tried to restore the national cohesion of Jordanian society by mobilizing influential forces from Jordanians from west and east of the Jordan River), and this transfer came after the Council of Ministers canceled the Foundation Law No. (26) 
According to Temporary Law No. (45) of 1973, followed by Temporary Law No. (5) of 1974, which stipulates the conversion of the Corporation into a private joint stock company (in which the government owns $40 \%$ of the shares, and the remaining $60 \%$ of the shares were offered to the private sector) and the process ended on 1 September 1975, after the full share of the government was sold, and ownership of it reverted to a small private group.

Al-Rai and Al-Dustour newspapers have represented the prevailing line that has proven successful in the Jordanian press experience from its inception until now, and the level reached by these two newspapers constitutes an acceptable standard for journalistic work in Jordan to some extent, despite the state of (instability) that it was experiencing in the transition from year to year. On the contrary, under the influence of the existing political authority, the two journalists have proven their success as they are still on the throne of the Jordanian daily press, as there are currently six daily newspapers in Jordan: Al-Rai, Al-Dustour, and Al-Ghad, which were established in 2003, Al-Nabatat, Al-Ummam and Al-Shaab.

With the entry of the press into the era of electronic media, we notice that many newspapers, especially the weekly, preferred to switch to electronic media and were no longer printed on paper, or turned into monthly or nonperiodical magazines. Currently, six Arabicspeaking and English-speaking daily newspapers remain in Jordan, which are the Jordan Times and many weekly newspapers that At one point it reached forty newspapers, but now all of them have turned to electronic websites.

These newspapers appeared in Jordan after the lifting of martial law and the return of democratic life in $1989 \mathrm{AD}$, when the reader was eager to change his reading style, so he clearly inclined to read the weekly newspapers.
On December 13, 1989, a new phase witnessed a breakthrough in the press crisis to coincide with the democratic process that Jordan entered after the return of democratic life to it, and the subsequent political events whose influence overtook Jordan to the Middle East region and the whole world with the collapse of the Soviet Union and the second Gulf War with the occupation of Iraq To Kuwait and then the Madrid Conference in what was known as the peace process in the Middle East in 1991 AD and the Wadi Araba Agreement in the year 1994 CE.All these factors affected the Jordanian media scene, which led to the emergence of cultural and literary productions that imposed themselves on the Jordanian cultural scene affected by political events, whether it was prose or poetry. Or theater, that is, politics has dominated the cultural scene, so most cultural works contain political events, unlike what was in the emirate and the beginning of the fifties when culture dominated the political scene with the tyranny of literature and culture over the political press.

Previous studies:

Researchers have received great interest in studies related to news agencies, especially international and their relationship with newspapers, and this attention has focused on many aspects, perhaps the most important of which is the effect of this dependence on the independence of newspapers. Below is an overview of some of these studies.

1- Study: Aisha Mahmoud Atef (2016) entitled: The design and websites of international news agencies in the Arabic language and its relationship to the ease of using these websites to obtain news.

The study aimed to identify the role of electronic structural elements in designing the websites of international news agencies speaking in the Arabic language, to identify the extent to which these sites use design elements, and to identify the most important news agencies and the reasons for the public's use of these sites, and this study belongs to descriptive studies, and the study used the survey method and adopted On the method of comparison, the shape analysis tool and the survey 
tool, the study sample was represented by the websites of French news agencies, Reuters and Anadolu Agency, in addition to a sample of journalists' users of these sites, and the study reached a set of results, the most important of which are:

- The three agencies varied in the languages used in the design, and the French News Agency was only able to comment on the material.

The three agencies have been interested in placing links on their main pages of their social media accounts (Facebook, Twitter, and others).

The results indicated that Reuters is one of the most important agencies that journalists prefer to use.

- The speed of obtaining information was one of the most important features of the websites of Arabic-speaking news agencies.

- The study indicated that the use of pictures and graphics came first, and that the most important method preferred by journalists while moving to read the full text was through the title as the main link.

2- Study: Marji Gomaa Starr (2013) entitled: Effectiveness of National News Agencies in the Era of Free Flow of Information, Sudan News Agency (SUNA) as a model.

The study aimed at identifying the effectiveness of national news agencies in the era of the free flow of information, as well as revealing the extent of their resilience in the future in light of communicative globalization and the free flow of information and knowledge of the technological and technical development of these agencies and their news coverage, and the researcher used in this study both the survey method and the study methodology The researcher used both the survey and interview as one of the tools for gathering information, and the researcher also chose the intentional sample to suit the study sample.

The study concluded with several results:

1- National news agencies influence traditional media through their services, but this influence varies from unit to unit.
2- The study showed that traditional media sometimes resort to taking their news and information from national agencies.

3- The study confirmed the success of national agencies in their coverage of local events and national issues.

4- The study affirmed that among the appropriate proposals to develop and qualify national news agencies is an increase in financial allocations, administrative stability, training of cadres, and introduction of technology and modern technologies.

5- The study also showed that the existence of the Internet has actually affected national news agencies and in turn opened these agencies new outlets to provide their services.

3- Study: May Mustafa Abdel-Razek (2013), entitled: Factors Affecting Arab and International News Agencies' Coverage of Events. Study of the content and the communicator.

The study aimed to uncover the monitoring, analysis and interpretation of the factors affecting the coverage of events on the part of news agencies, whether Arab or international in general, and by application to the two study agencies in particular. International and Arab news agencies, in addition to their customers or beneficiaries of their services from the various media (newspapers, satellite news channels, radio stations, and websites). The study reached a set of results, the most important of which are:

- The existence of a positive relationship with statistical significance between the factors affecting the performance of newspapers in the news agency, and the factors affecting the quality of the performance of news agencies when covering events.

- The quality of the inputs of the agencies under study is good, with the exception of the Middle East News Agency, whose results stated that the level of these inputs in terms of their degree of quality is average.

- The results reached an agreement between the two samples of contact persons in news agencies 
and customers who are subscribers of their services.

- The study found a number of news frameworks that were similar and differed in other aspects, at the level of the events under study.

4- Study: Yasmine Jamal Muhammad Al-Shannaq (2013), entitled: A survey study's reliance on Jordanian daily newspapers to obtain news and information.

The study aimed to identify the extent of the Jordanian reader's dependence on Jordanian daily newspapers as a source in obtaining various news and information, whether related to political, economic, or social issues, and others, and to know the role of daily newspapers in influencing readers when hot events occur at all local, Arab and international levels. And the extent of the influence of local and international news agencies on the work of the Jordanian daily newspapers in obtaining and publishing the news. The researcher relied on the field survey method for a sample of the teaching and administrative staff at Yarmouk University amounting to 527 items, and the results of the study showed the following:

- The Jordanian daily newspapers ranked third as a source for the reader's reliance on them in obtaining news and information, at a rate of $9.6 \%$. The Internet ranked first with a rate of $47.8 \%$, and satellite channels ranked second with a percentage of $32.3 \%$, as the results indicate that Jordanian daily newspapers are not a major source for the Jordanian reader to obtain news and information.

5- Study: Ayman Musa Ibrahim Al-Falih (2012), entitled: The role of the Jordan News Agency (Petra) in the local news industry from the viewpoint of journalists in daily newspapers.

The study aimed to monitor and analyze the coverage of the Jordan News Agency (Petra) of local news, as a tool for the main news and information sources for the Jordanian press. It also aimed to research the foundations and criteria used in collecting, selecting, editing and broadcasting news. The study relied on the descriptive approach, and the study population consisted of working Jordanian journalists In the field of journalism, the researcher used a data collection tool to collect information.

The study reached a set of results, the most important of which are:

- It was found that the level of importance of news professionalism in the Jordanian News Agency (Petra) was of moderate importance from the sample's point of view.

- The level of news value in the Jordan News Agency (Petra) through this study was high, and this is clear evidence of the study sample's interest in the value of the news presented by Petra Agency.

- It was found that the level of importance of the size and type of coverage in the Jordanian News Agency (Petra) from the point of view of the study sample was medium.

6- A study: Hussein Ismail Haddad (2010), entitled: Availability of interactive applications on Iraqi news agency websites on the Internet .. An analytical survey study of a sample of electronic news agencies.

The study aimed to determine the extent to which the sites of Iraqi local news agencies on the Internet benefit from the interactive features provided by the network, and to identify the levels of this interaction that have been employed, by examining the extent of their availability or lack thereof in those sites.

The study relied on the descriptive survey method and within this approach the content analysis tool was used. The current study discusses the extent to which the Iraqi News Agency on the Internet keeps pace with this development and the availability of interactive applications on its sites by studying six of them. The study concluded that the study sample achieved a percentage of $46.62 \%$ of the availability of interactive elements according to the dimensions used, which is a percentage that the researcher saw indicating limited use of interactive elements in the websites of Iraqi news agencies on the Internet. According to Al-Netabaj, the websites of Iraqi news agencies on the Internet showed a full percentage of 4783 
attendance, especially the immediate update of news, as they appeared by the hour, minute, and sometimes by second at the beginning of each news and in another site, usually higher than the site.

The researcher also concluded that the Iraqi news agencies' electronic websites are not keen on diversity in the content options and its multiplicity for the user in the interface of the site, where it ranked third with a rate of $51.21 \%$, although the interface page is the portal of the site and the address of its efficiency for the user, and the websites of all kinds are keen to provide the expertise of this The dimension is as far as possible for various informational and technical purposes, while the option to respond to the users' desires came first at the level of providing its own interactive elements, which were limited to achieving integrated proportions in terms of the presence of a postal connection to the site and the presence of the definition link to the site.

7 - Study: Lamia Bella Ali Nasrallah (2007), entitled: African News Agency, Communication and Development Issues.

The study aimed to know the role that the agency plays in linking African countries with each other in crucial issues and facing the challenges of global media. The researcher used the historical method to be used in primary data, documents and records to track historical events, origin and development, and to analyze documents, charters and writings between the agency and other bodies such as the Organization of African Unity and UNESCO. The researcher used primary data to obtain it from some of the people who

Some ties to the agency connected them through the interview.

The most important findings of the study:

1- The African News Agency, PANA Press, has suffered and is still suffering from a lack of financial and human resources to grow and develop like any other African project.

2- The decisions of the agency's board of directors prevail over enthusiasm, but those decisions do not come down to reality and do not act only in very small proportions.

3- Financial contributions and debts are matched by some lax payment by African national agencies, which causes the Agency's financial crises.

8- Study: Haifa Ayoub Jajawi (2007), entitled: electronic archiving of Arab news agencies' websites, Cybrarians Journal,

The aim of the research is to present the methods and practices of electronic archiving used in the websites of Arab news agencies on the Internet and the methods of searching in them. It also aims to examine those methods in order to reach the most useful ones for beneficiaries and researchers. Information, the research focuses in practice on the research methods of Arab news agencies for news in both text and visual forms, reaching the search results that have been enhanced with tables to clarify this. Use them in other links. The research also provided media information about the websites of Arab news agencies. In its conclusion, the research concluded with some matters that must be taken into account in the websites of those agencies. One of them is that some news agencies list news from the oldest to the most recent, and this of course is incorrect, as it is known that the agency's interest is the basis for transmitting the news quickly. Therefore, listing the news ascending from the newest to the oldest allows the reader to get acquainted with the latest news.

9- Study: Shadia Shaker Khaled Khairallah (2006), entitled: News coverage in the states at the Sudan News Agency, a case study on the Gezira State office.

The study aimed to determine the type of news that the agency is working to transmit from the state of the island. And access to a scientific approach in news coverage. And stand on the editorial arts used for the state office of the island. The researcher used the survey method and the content analysis approach. The researcher used the personal interview and observation.

Among the most important findings of the study: 
1. The study emphasized the importance of the role that the Sudan News Agency should play in linking the states of Sudan with news, embodying the meanings of nationalism, consolidating the foundations of national unity, and contributing to the consolidation and establishment of the democratic system.

2. The study revealed a shortage of cadres and low efficiency for workers in the state office.

3. The study revealed the slow implementation of the project to introduce technology to connect the states with the national information network of Sudan News Agency.

10- Study: Fayez Al-Shehri (2003), entitled: The Reality and Future of Daily Newspapers on the Internet, a comprehensive survey of editors-inchief of Saudi newspapers with electronic editions.

The study aimed to uncover the reality of Saudi daily newspapers published in the Arabic language on the Internet, and to clarify the reasons that led these newspapers to launch electronic copies, and through the editors 'opinions of the future of journalism. And to provide a general picture of the status of Saudi electronic newspapers, and the services provided by their websites on the Internet. The study used the descriptive and analytical method through a comprehensive survey of the members of the study community represented by all the editors-inchief of the Saudi newspapers issued in the Arabic language and that have websites on the Internet. The results showed that electronic newspapers will still exist alongside the printed press, but without a noticeable development, especially in terms of material resources, and the problem is further complicated by the high percentage of young people who are usually referred to even in developed countries as less interested in reading print newspapers in particular, than online journalism as well. Today, eight daily newspapers are published in the Kingdom printed in the Arabic language: "AlBilad", "Al-Nadwa", "Al-Madina" and "Okaz" from the western region, "Riyadh" and "AlJazeera" from the central region, and "Al-Youm" from the eastern region and "Home "from the southern region. As Al-Bilad and Al-Nadwa newspapers do not have websites, and the answers of Saudi newspaper editors-in-chief revealed the lack of clarity of the editorial and administrative policies followed in managing and managing the website's content.

\section{The study problem and its importance}

The reliance of the Jordanian media, especially the three newspapers subject of study, namely AlRai, Al-Dustour, and Al-Ghad on the Jordan News Agency in obtaining news, created a state of dependency between this government-owned agency and the three newspapers, where the government owns part of the shares of Al-Rai and Al-Dustour and dominates these two journalists while it is It does not own shares in Al-Ghad newspaper, but it is considered the largest advertiser in it.

The three newspapers have become the largest carrier of news issued by the Jordanian news agency "Petra", as they are considered official spokesmen for the Jordanian government and express the government's view of what is happening.

This contributed to the fact that the three daily newspapers are the main carrier of news issued by the Jordanian News Agency and the promoter of the news issued by it. Absent from the other point of view.

Hence, the research problem is determined in identifying the extent of newspapers accreditation

The Jordanian daily has to rely on the Jordanian news agencies, Petra, to obtain news and the extent of intellectual independence that these newspapers enjoy, as the role of the Jordanian News Agency has become a dominant role over newspapers and newspapers have become completely dependent on the Jordanian News Agency in obtaining news, especially local ones. 


\section{Objectives of the study}

This study aims to find out the relationship between the three Jordanian newspapers, the subject of the study, with the Jordanian News Agency "Petra" and its effect on the independence of Jordanian newspapers, with an explanation of the type of relationship that

The Jordanian newspapers under study are linked to the Jordanian News Agency "Petra" and to know the number of news published in these newspapers and made by the Jordanian News Agency "Petra" and the effect that this has on the Jordanian public that consumes this news and its impact on the independence of the three Jordanian newspapers.

\section{Study assignments}

Based on the results of previous studies, which the researcher reviewed, and the tribal study he conducted on a brief sample of news, he formulated the hypotheses as follows:

Jordanian newspapers rely heavily on Jordanian news agencies to publish local news

- There is a relationship of dependency between the Jordanian newspapers and the Jordanian News Agency.

Jordanian newspapers cannot do without the Jordan News Agency.

- The Jordanian News Agency conveys its viewpoint through the news.

- The Jordan News Agency is a spokesperson for the Jordanian government and publishes news from a unilateral perspective.

- The Jordan News Agency does not appear in news that contradicts the government's viewpoint, and therefore it expresses one point of view.

\section{Study questions}

Has the Jordan News Agency reduced newspapers' independence?

Did the Jordan News Agency contribute to newspapers' inaction in the news industry??

Has the Jordan News Agency reduced newspapers' dependence on itself for getting news?
Did the Jordan News Agency take control of newspapers in Jordan?

Did the Jordan News Agency contribute to limiting the free flow of information in Jordan?

Did the Jordanian News Agency weaken the Jordanian media?

Are the Jordanian newspapers unable to get rid of the Jordanian News Agency's control over them?

Procedural definitions

News agencies : They are institutions that provide a news service, as they collect news and cover events with pictures, words and audio. It provides its news services to various media institutions such as radio, television and newspapers.

Newspapers : - They are institutions based on gathering and analyzing news, verifying its authenticity and presenting it to the public. These news are often related to developments in the political, local, cultural, sports, or social arena, among others.

\section{Study quality and methodology}

This study is classified within the descriptive research that aims to study the current conditions of phenomena in terms of their characteristics, shapes, relations, and factors affecting these phenomena, and the descriptive method is concerned with studying the present of phenomena and events, unlike the historical method that studies the past, noting that the descriptive approach often includes processes of prediction for the future. Events.

This study relied on the survey method through the agency study that the main daily newspapers in Jordan deal with, namely Al-Ra'i, Al-Dustour and Al-Ghad. The researcher counted the number of local news published in these three newspapers that were taken from the Jordanian News Agency.

\section{Study population and sample:}

The study population consists of the news that was published in the daily newspapers Al-Rai, AlDustour and Al-Ghad, where the study sample was taken from these newspapers and the newspapers were tested during the study period, which lasted for fifteen days. To two types are 
self-sources or taken from the Jordanian Sons Agency.

442 news articles published in Al-Rai newspaper were counted, studied and classified, 588 articles were published in Al-Dustour newspaper, studied and classified, and 298 articles were published in Al-Ghad newspaper, studied and classified during the study period.

\section{Statistical treatment:}

The answers were unpacked and entered into the computer memory. The statistical package for social sciences 'spss' was used in analyzing the data. The researcher used frequencies and percentages.

\section{Test the hypotheses of the study and discuss them:}

1- Jordanian newspapers rely heavily on the Jordan News Agency to publish local news

To answer this hypothesis, the researcher counted the number of local news published in Jordanian newspapers (Al-Rai, Al-Dustour, Al-Ghad) during the period 1-20 until 2/4/2021, and knowing the main source of each news by calculating the frequency, percentage and tables (1-3) Explain that.

Table (1) shows the source and number of local news published by Al-Rai newspaper and the percentages.

$$
\mathrm{N}=(535) \text { local news: }
$$

\begin{tabular}{|l|l|ll}
$\begin{array}{l}\text { The number } \\
\text { local news }\end{array}$ & From self-sources & $\begin{array}{l}\text { News number from } \\
\text { Petra }\end{array}$ & $\begin{array}{l}\text { The percentage of } \\
\text { news from Petra }\end{array}$ \\
\hline 535 & 442 & 144 & $38 \%$
\end{tabular}

Table (2) shows the source and number of local news published by Al-Dustour newspaper and the percentages.

\begin{tabular}{|l|l|ll} 
News number & From self-sources & $\begin{array}{l}\text { News number from } \\
\text { Petra }\end{array}$ & $\begin{array}{l}\text { The percentage of } \\
\text { news from Petra }\end{array}$ \\
\hline 588 & 368 & 220 & $37 \%$
\end{tabular}

Table (3) shows the source and number of local news published by Al-Ghad newspaper and the percentages.

\begin{tabular}{|l|l|l|l} 
News number & From self-sources & $\begin{array}{l}\text { News number from } \\
\text { Petra }\end{array}$ & $\begin{array}{l}\text { The percentage of } \\
\text { news from Petra }\end{array}$ \\
\hline 298 & 184 & 114 & $39 \%$
\end{tabular}

Through the tables (1-3) we can see the following: 1) Al-Rai newspaper relies on the Jordan News Agency to publish news by a percentage (38\%), while it relies on publishing news from its source at a percentage $(62 \%)$.

2) Al-Dustour newspaper relies on the Jordanian news to publish news by a percentage (37\%), as it 
relies on publishing news from its source by a percentage $(63 \%)$.

3) Al-Ghad newspaper relies on the Jordan News Agency to publish news by a percentage (39\%), while it relies on publishing news from its source by a percentage $(61 \%)$.

The researcher believes that Jordanian newspapers (Al-Rai, Al-Ghad, Al-Dustour) rely heavily on the Jordan News Agency to publish news, at a percentage $(38 \%)$.

\section{2 . There is a dependency relationship}

\section{between Jordanian newspapers and} international news agencies.

To answer this hypothesis, the researcher used the Pearson correlation test to find out the correlation relationship between Jordanian newspapers and international news agencies, as it was found that: 1.The existence of a dependency relationship between the Jordanian newspaper, Al-Rai and the Jordanian News Agency, as the correlation coefficient $(\mathrm{R})$ reached $(38 \%)$, which is a high correlation value.

2.The existence of a dependency relationship between the Jordanian newspaper Al-Dustour and the Jordan News Agency, as the correlation coefficient (R) reached (37\%), which is a high correlation value.

3.The existence of a dependency relationship between the Jordanian newspaper Al-Ghad and the Jordanian News Agency, as the correlation coefficient (R) reached (39\%), which is a high correlation value.

4.The existence of a dependency relationship between the Jordanian newspapers and the Jordan News Agency, as the correlation coefficient $(\mathrm{R})$ reached (38\%), which is a high correlation value.

\section{3- Jordanian newspapers cannot do without the} Jordan News Agency.

To answer this hypothesis, the researcher has adopted tables (1-3), which illustrate the extent of the Jordanian newspapers 'ability to dispense with the Jordan News Agency. Through tables (1-3), the following is evident: -

1. The Jordanian Al-Rai Newspaper cannot do without the Jordan News Agency, as the Jordanian Al-Rai newspaper relies on the Jordan News Agency to report news by a percentage $(38 \%)$.

2. The Jordanian Al-Dustour newspaper cannot do without the Jordanian News Agency, as the Jordanian Al-Dustour newspaper relies on the Jordanian News Agency to report news by a percentage $(37 \%)$.

3. The Jordanian Al-Ghad newspaper cannot do without the Jordan News Agency, as the Jordanian Al-Ghad newspaper relies on the Jordanian News Agency to report news by a percentage $(39 \%)$.

4. Jordanian newspapers cannot do without the Jordan News Agency, as Jordanian newspapers rely on the Jordanian News Agency to report news by a percentage (38\%).

\section{4- The Jordan News Agency conveys its viewpoint through the news.}

To answer this hypothesis, the researcher has adopted tables (1-3), which illustrate the extent of the viewpoint of Jordanian newspapers through the news, and through tables (1-3) the following are revealed:

1.Al-Rai newspaper transmits its point of view through the news by a percentage (38\%).

2.Al-Dustour newspaper transmits its point of view through the news by $37 \%$.

3.Al-Ghad newspaper transmits its point of view through the news by $39 \%$.

4.Jordanian newspapers transmit their point of view through the news by a percentage $(38 \%)$.

5. Results :-

- Jordanian newspapers still rely heavily on the Jordan News Agency to obtain Arab and international news, especially local, which confirms the theory of dependency in the floating relationship between the Jordanian News Agency and the Jordanian daily newspapers Al-Rai, the Constitution and AlGhad, as these newspapers obtain from the Jordan News Agency by more than $37 \%$.

- There is a great similarity in the content and content of the three Jordanian daily 
newspapers, Al-Rai, the Constitution, and AlGhad, as there is a clear similarity in the percentage of local news, while there is a great similarity in the percentage of Arab and international news of more than $90 \%$, and this similarity indicates that the content of the three newspapers is closely related and that the differences are in The content between the three newspapers is very little.

- The Jordanian News Agency "Petra" controls the flow of information and the flow of news from the source to the public, especially news related to the work of official institutions in Jordan. This agency monopolizes the publication of official news and owns the broadcast of many news exclusively, especially news issued by the Jordanian Royal Court, the Presidency of the Government, and many more. From the official authorities.

- The study indicated that daily newspapers consume the news issued by the Jordan News Agency, Petra, by 38\%, while there are a lot of news issued by this agency, but the source of this news is not mentioned nor is it mentioned that it is from the Jordanian News Agency.

- The study indicated that the news consumed by newspapers issued by the Jordan News Agency is positive news and represents one point of view, which is the view of the Jordanian government and its affiliates, while the other viewpoint and negative news is absent from this agency, which is owned by the Jordanian government by $100 \%$.

- The study showed that there was a one-way flow of news from the government and its official agencies towards the public, while the flow of news in the other direction from the public to the agency was not present.

- This led to the daily newspapers losing their independence because their reliance on the news agency made them largely dependent on it. The reliance of one party on another in obtaining information and news in a large percentage deprives him of the intellectual independence that must be built between two equal parties. Unpowered, and there is no denying the fact that there is an imbalance in the flow of news 0

\section{Recommendation}

The researcher came up with a set of recommendations as follows:

1- The researcher recommends the Jordanian daily newspapers, Al-Rai, Al-Dustour and Al-Ghad to rely on themselves to obtain news and to reduce reliance on the Jordan News Agency and other agencies in obtaining news.

2- The study recommends motivating the journalists working in the three daily newspapers to obtain news from its source and not to rely on the Jordanian News Agency and to create a diversity of news and that the journalists working in these newspapers cover the news themselves and obtain it from its sources instead of relying on the Jordanian News Agency.

3- The researcher recommends the Jordanian newspapers to appoint representatives for them in all governorates, districts, ministries and official institutions.

4- The researcher recommends the necessity of reducing the publication of news issued by agencies, including the Jordanian News Agency "Petra", and that news be made in newspapers instead of getting them ready. This does not reduce the independence of newspapers.

\section{Resources and References}

[1] Majed Al-Khodari, Al-Khobar Industry, Amman: Osama House for Publishing and Distribution, 2020, pg. 198

[2] The official website of the Jordan News Agency "Petra" petra.gov.jo

[3] Muhammad Jamal Al-Far, The Media Lexicon, Amman: Osama House for Publishing and Distribution, and the AlMashriq Cultural House, 2006.

[4] Muhammad Ali Al-Qawzi, The Emergence and Development of Communication Means, Beirut: Arab Renaissance House, 2007.

[5] Hosni Mohamed Nasr, Introduction to Mass Communication (Entrances and 4789 
Ways), Beirut: Al-Falah Library for Publishing and Distribution, 2001.

[6] Al-Khudari, Majed, Introduction to Communication and Media Science, Oman: Al-Darb Newspaper Publications, 2016 p.123

[7] Basem Sakkijha, The Development of Journalism and Journalism in Jordan, Amman: Dar Al-Sindbad, 1999 AD

[8] Issam Suleiman Musa, The Development of the Jordanian Press 1920-1997, Jordan History Publications, Amman, 1998 AD

[9] Aisha Mahmoud Atef, Design and Websites for International ArabicSpeaking News Agencies and Its Relation to the Ease of Using These Websites to Get News, Unpublished MA, Beni Suef University, Faculty of Information, 2016.

[10] Marji Gomaa Star, The Effectiveness of National News Agencies in the Era of Free Flow of Information, Sudan News Agency (SUNA) as a model in the period 2009-2013, Master Thesis, Sudan, Omdurman Islamic University, Faculty of Information, 2013

[11] May Mustafa Abdel-Razek, the factors affecting Arab and international news agencies' coverage of events. Study of the content and communicator, unpublished Ph.D., Cairo University, Faculty of Mass Communication, Department of Journalism, 2013

[12] Yasmine Jamal Muhammad AlShannaq, The reader's reliance on Jordanian daily newspapers to obtain news and information, survey study, master's thesis, Jordan, Yarmouk University, Faculty of Information. 2013.

[13] Ayman Musa Ibrahim Al-Fulaih, The Role of the Jordan News Agency (Petra) in the local news industry from the viewpoint of journalists in daily newspapers, MA Thesis, Jordan, University of the Middle East, College of Media, 2012.

[14] Hussein Ismail Haddad, The extent of availability of interactive applications in the websites of Iraqi news agencies on the Internet .. An analytical survey of a sample of electronic news agencies, Iraq, Journal of Dhi Qar Arts - Faculty of Arts Dhi Qar University -, Volume 1, Issue 2, 2010.

[15] Lamia dulling the victory of religion, the African News Agency and the issues of communication and development, message Ph.D. is unpublish ed, University of Umm Omdurman Islamic University, Faculty of Media 2007.

[16] Haifa Ayoub Jajawi, Arab News Agency Websites Archiving, Cybrarians Journal, Electronic Journal in the Field of Libraries and Information, Issue 12, March, 2007. Link: http://search.mandumah.com/Recor $\mathrm{d} / 507708$ 